\title{
The Impacts of Anthropogenic Activities on the Surface Sediment Quality of Okpare Creek in Niger Delta, Nigeria
}

\author{
Ikegu Onajite*, Olomukoro John Ovie \\ Department of Animal and Environmental Biology, University of Benin, Benin City, Nigeria \\ Email: *jite4arho@gmail.com
}

How to cite this paper: Onajite, I. and Ovie, O.J. (2022) The Impacts of Anthropogenic Activities on the Surface Sediment Quality of Okpare Creek in Niger Delta, Nigeria. Open Access Library Journal, 9: e7686.

https://doi.org/10.4236/oalib.1107686

Received: October 3, 2021

Accepted: February 25, 2022

Published: February 28, 2022

Copyright $\odot 2022$ by author(s) and Open Access Library Inc.

This work is licensed under the Creative Commons Attribution International License (CC BY 4.0).

http://creativecommons.org/licenses/by/4.0/

\begin{abstract}
Anthropogenic activities along Okpare creek are mainly farming, irrigation, fishing, domestic activities, lumbering and sand mining and these activities can alter some natural components of the creek, hence this study aimed to assess the impact of anthropogenic activities on the surface sediment quality of Okpare Creek in Niger Delta. The sediment samples were collected and analyzed for physiochemical parameters as well as heavy metal content. Sediment quality parameters examined were $\mathrm{pH}$, electrical conductivity (EC), total organic carbon (TOC), total organic matter (TOM), percentage (\%) sand, clay, silt and Heavy metals-cadmium, chromium, iron, zinc, lead, copper and nickel. Heavy metals were determined by the samples being subjected to Nitric-perchloric acid digestion and thereafter an atomic absorption spectrophotometer was used to determine the concentration of the metals. Data were analyzed with ANOVA and Duncan Multiple Range Test. With the exception of $\mathrm{pH}$ and cadmium, the other physicochemical parameters differ significantly $(\mathrm{p}<0.05)$ across the station. The trend for the heavy metals showed their occurrence in terms as iron $>$ zinc $>$ chromium $>$ lead $>$ copper $>$ cadmium. The principle component analysis (PCA) revealed that eigenvectors classified the physicochemical parameters into four components which all together accounted for $85.320 \%$ of the variance in the data set. The contributions were as follow-component 1, 2, 3 and 4 accounted for $27.225 \%$, $25.624 \%, 21.229 \%$ and $11.242 \%$ respectively. The high eigenvectors for components 1, 2, 3 and 4 were recorded for $\mathrm{Cr}, \mathrm{Fe}, \mathrm{Zn}, \mathrm{Pb}$ and $\mathrm{Ni}$; \% sand, clay and silt; \% TOM and $\mathrm{TOC}, \mathrm{Cd}, \mathrm{Cu} ; \mathrm{pH}$ and electrical conductivity respectively. Thus the influence of anthropogenic activities impacted all the parameters analyzed. It is needful that environmental friendly approaches be adopted in order to avoid loss of biodiversity, loss of means of livelihood and health hazards for the locals.
\end{abstract}




\section{Subject Areas}

Ecology, Zoology

\section{Keywords}

Sediment, Niger Delta, Anthropogenic Activities, Physicochemical Parameters, PCA

\section{Introduction}

The increase in population has led to the surge in scientific research of the Niger Delta aquatic bodies (Davies and Tawari, 2010) [1]. The petroleum industries, particularly in the Niger Delta area greatly have contributed to aquatic environmental degradation and pollution (Ite et al., 2013) [2]. Many studies currently being done on various areas of hydrological studies include the variability in water and sediment physico-chemistry, bacteriological, plankton, periphyton, macrophytes, benthos and fisheries (finfish and shellfishes) and also the extent of pollution in order to ascertain the health status of these aquatic bodies as well as other water bodies in Africa (Farouk and Ahmed, 2019 [3]; Hasaballah et al., 2019 [4]).

Sediments are an essential component of aquatic ecosystem. They are formed from soil erosion or from the decomposition of plants and animals (USEPA, 2002) [5]. Wind, water and ice help carry these particles to rivers, lakes and streams. As an important component of the aquatic ecosystem, sediments serve as habitat and or spawning/breeding grounds for a wide range of aquatic organisms, usually referred to benthic organisms, the maintenance of its health and by extension that of the organism it supports becomes paramount (Wokoma and Friday, 2017) [6]. Anthropogenic activities and particular dredging have a consequential effect on aquatic ecosystem. In line with Elijah et al., (2008) [7], dredging has been reported to cause the re-mobilization of contaminants particularly heavy metals on aquatic animals and plants. Heavy metals are a threat not just to aquatic species but other organisms that depend on them.

Sediments have been studied extensively all around the world (Davies and Tawari, 2010) [1] and have being reported to be potential reservoirs for many contaminants (Mucha et al., 2003 [8] and Praveena et al., 2007 [9]) as well as play pivotal role in the determination of the pollution status of rivers and can also be employed in reviewing the history of pollution in river ecosystem ( $\mathrm{Yu}$ et al.; 2001 [10]; Wepener and Vermeulen; 2005 [11]). Therefore, sediment quality data provide essential information for evaluating ambient environmental quality conditions in aquatic ecosystem. The Okpare Creek is one of the coastal creeks in the Niger Delta which is exposed to varying influence of anthropogenic activities. Consequently, it became necessary for this study. The aim of this study is to provide information on the levels and distribution of selected heavy metals to- 
gether with other influential parameters in sediments from Okpare Creek.

\section{Description of the Study Area}

The study area is located between latitude $05^{\circ} 27 \mathrm{~N}$ and $05^{\circ} 33 \mathrm{~N}$ and longitude $005^{\circ} 53 \mathrm{E}$ and $006^{\circ} 04 \mathrm{E}$ along Okpare Creek, Ughelli South Local Government, Delta state, Nigeria (Figure 1). The creek runs North-West to South-East. The Okpare creek took its source from the Umuaja in Umutu and River Niger and empty into Atlantic Ocean at Forcados. This area within the equatorial region having two climatic regimes: the wet season, which begins in April and lasts till October and the dry season from November to March. With the incidence of climate change, the timing of the seasons fluctuates from year to year. The annual rainfall ranges from $47.1 \mathrm{~mm}-678.1 \mathrm{~mm}$ with temperatures varying between $23^{\circ} \mathrm{C}$ and $37^{\circ} \mathrm{C}$ in the afternoon and dropping to between $18^{\circ} \mathrm{C}$ and $22^{\circ} \mathrm{C}$ at night (Ejoh et al. 2018a [12] and 2018b [13]).

The main geological elements of the area at varying depths in thousands of meters are the Benin formation (which is the youngest) underlined by Agbada formation and then followed by the oldest, the Akata formation, and these three formations are differentiated by their ages and by degrees of compartment. Their ages become progressively younger in a down-dip direction. The Benin formation is the main Aquifer in the study area and regionally, is the main Aquifer of the Niger Delta (SPDC, EIA, 2004) [14].

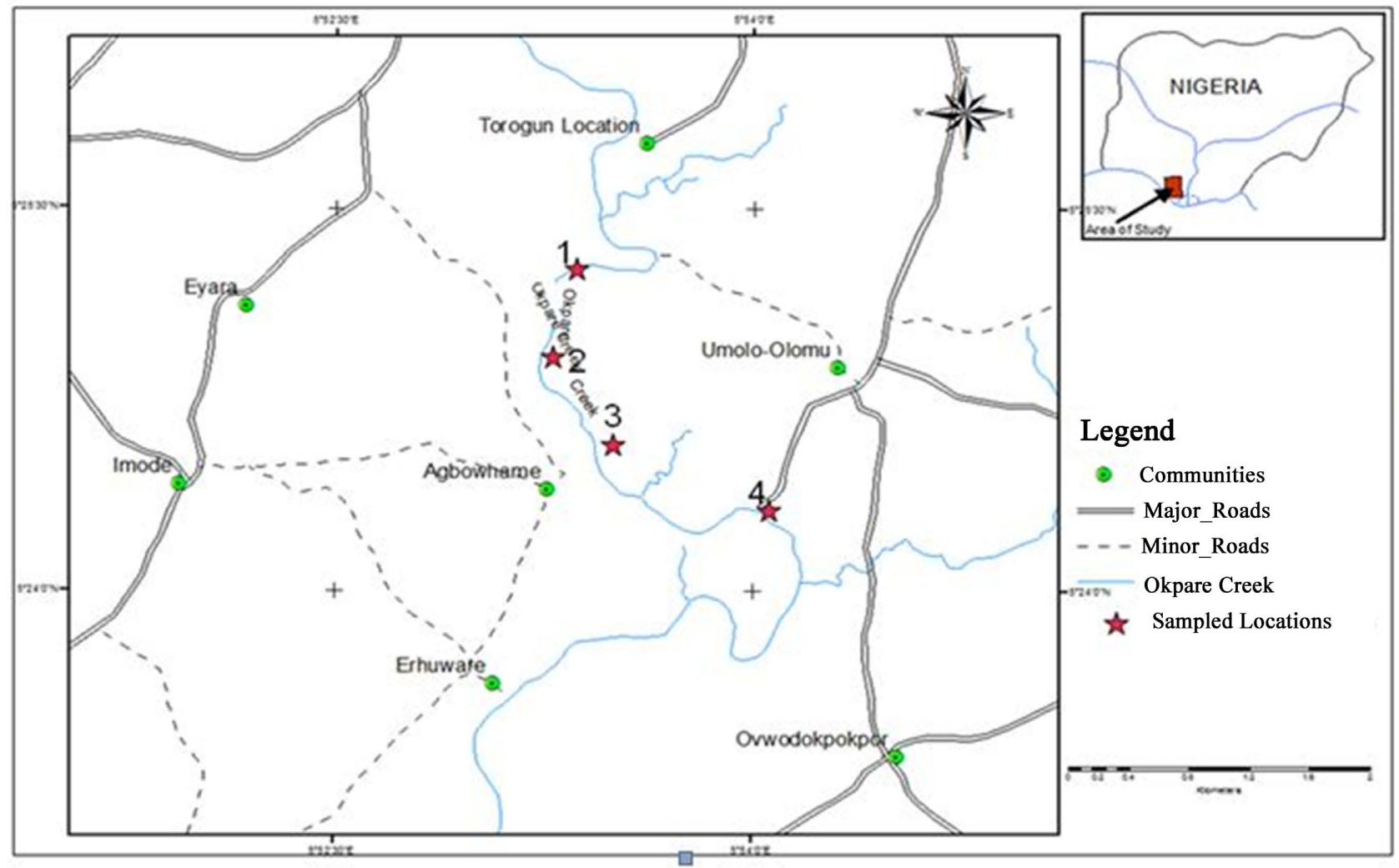

Figure 1. Map of study area showing the sampled locations along Okpare Creek. 
In consideration of the peculiar ecological settings and dredging activities, samplings of four (4) stations were established along the stretch. The fringe bank vegetation composition across these stations was similar.

Station 1: The substratum of this station consists mainly of sharp, coarse sandy soil, dead and decaying organic matter from marginal plants and trees at the bank. The depth of the water at the creek is 12 meters, and the velocity is 0.8 $\mathrm{m} / \mathrm{s}$. The vegetation is fringed and marginal.

Station 2: This station is located approximately $4 \mathrm{~km}$ away from station 1 , the substratum consists of sand, clayey soil, dead, and decaying organic matter. The depth of the creek in this area is approximately 18 meters deep, and the velocity is $0.84 \mathrm{~m} / \mathrm{s}$.

Station 3: This station is located beneath the bridge popularly known as the Okpare-Olomu Bridge. This station is approximately $5 \mathrm{~km}$ away from station 2 , and the depth of the water is approximately 19.4 meters and the velocity of 0.92 $\mathrm{m} / \mathrm{s}$. The substratum is coarse sand in the mid-area with a few muddy portions by the bank.

Station 4: This station is located close to a jetty, and it is approximately $6 \mathrm{~km}$ away from station 3 , and the depth of the water is approximately 27.6 meters and a velocity of $1.2 \mathrm{~m} / \mathrm{s}$.

\section{Sediment Samples Collections and Analyses}

Composite of sediment samples were collected with light dredge once a month from each sampling station for twenty four months (February 2012-January 2013) mostly during the low tides. They were stored in a labeled polythene bags and kept in an ice-chest box before transferring to the laboratory. The collected sediments were air dried at room temperature in the laboratory. The dried samples were then crushed to fine texture in a ceramic mortar, re-packaged in labeled polythene bags and stored in the laboratory for physicochemical parameters including $\mathrm{pH}$, electrical conductivity(EC), percentage (\%) total organic carbon (TOC), percentage total organic matter (TOM), \% sand, \% clay, \% silt and heavy metals-cadmium, chromium, iron, zinc, lead, copper, and nickel. The sediment samples were dried to low constant weight, ground to powder and sieved using $2.0 \mathrm{~mm}$ mesh sized sieve ( $\mathrm{pH}$ and particulate size) and $0.5 \mathrm{~mm}$ sieve for other analyses and thereafter were digested using the conventional Nitric-perchloric acid digestion method. The digested samples were then analysed for heavy metals using flame atomic absorption spectrophotometer (AAS).

Inter-spatial comparisons of the levels of physicochemical parameters determined to test for significant differences in the physicochemical conditions using parametric analysis of variance (ANOVA). If significant value $(\mathrm{P}<0.05)$ were obtained in the ANOVA, Duncan multiple range (DMR) test was performed to determine the location of significant differences.

Principle component analysis (PCA) was applied to summarize the statistical correlation among the parameters and further identify the parameters most in- 
fluenced by the natural and anthropogenic activities on going in these areas.

\section{Result: Variations in the Sediment Physicochemical Parameters}

Table 1 below shows the intraspecific and interspatial variations for the analyzed physicochemical parameters in this study. With the exception of $\mathrm{pH}$ and cadmium, the other physicochemical parameters differ significantly $(\mathrm{p}<0.05)$ across the station. The $\mathrm{pH}$ values across the stations were acidic. The mean levels of electrical conductivity in individual stations were generally $<300 \mu \mathrm{S} / \mathrm{cm}$ and intraspecific variations peaked in station 1 . The total organic carbon and matter maintained similar variation, the minimum and maximum mean values were recorded in stations 1 and 3 respectively. Iron is the dominant heavy metal and its mean values ranged from $95.49 \mu \mathrm{g} / \mathrm{g}$ in station 2 to $312.40 \mu \mathrm{g} / \mathrm{g}$ in station 1 . The trend for other heavy metals showed that zinc $>$ chromium $>$ lead $>$ copper $>$ cadmium. With the exception of copper, the highest values of other heavy metals were recorded at station 1 while the lowest values were generally recorded in station 2. For the intraspecific, the maximum values were recorded in station 1 for all the heavy metals except lead and copper. For the particle matters including sand, clay and silt, their variations complement one another, station 1 recorded the lowest and highest values by sand and silt respectively, opposite of this variation was recorded in station 4 . The percentage level of clay peaked in

Table 1. Spatial variations in the sediment physicochemical parameters.

\begin{tabular}{|c|c|c|c|c|c|}
\hline $\begin{array}{c}\text { Sediment Physicochemical } \\
\text { Parameters }\end{array}$ & $\begin{array}{l}\text { Station } 1 \\
\bar{x} \pm S D\end{array}$ & $\begin{array}{l}\text { Station } 2 \\
\bar{x} \pm S D\end{array}$ & $\begin{array}{l}\text { Station } 3 \\
\bar{x} \pm S D\end{array}$ & $\begin{array}{l}\text { Station } 4 \\
\bar{x} \pm S D\end{array}$ & p-Value \\
\hline $\mathrm{Ph}$ & $4.57 \pm 0.37$ & $5.00 \pm 0.46$ & $5.02 \pm 0.58$ & $4.51 \pm 0.82$ & $\mathrm{P}>0.05$ \\
\hline Electrical Conductivity $(\mu \mathrm{S} / \mathrm{cm})$ & $295.16 \pm 145.94^{\mathrm{a}}$ & $149.94^{\mathrm{bc}} \pm 39.65$ & $131.99^{c} \pm 27.17$ & $231.13^{\mathrm{ab}} \pm 74.21$ & $\mathrm{P}<0.05$ \\
\hline Total Organic Carbon (\%) & $2.57^{\mathrm{a}} \pm 0.52$ & $1.87^{\mathrm{b}} \pm 0.45$ & $1.61^{\mathrm{b}} \pm 0.25$ & $1.90^{\mathrm{b}} \pm 0.72$ & $\mathrm{P}<0.05$ \\
\hline Total Organic Matter (\%) & $4.38^{\mathrm{a}} \pm 0.87$ & $3.24^{\mathrm{b}} \pm 0.78$ & $2.78^{\mathrm{b}} \pm 0.44$ & $3.27^{\mathrm{b}} \pm 1.21$ & $\mathrm{P}<0.05$ \\
\hline Cadmium $(\mu \mathrm{g} / \mathrm{g})$ & $0.67 \pm 0.87$ & $0.37 \pm 0.57$ & $0.33 \pm 0.42$ & $0.41 \pm 0.55$ & $\mathrm{P}>0.05$ \\
\hline Chromium ( $\mu \mathrm{g} / \mathrm{g})$ & $2.90^{\mathrm{a}} \pm 0.91$ & $1.36^{\mathrm{b}} \pm 0.68$ & $1.62^{\mathrm{b}} \pm 0.56$ & $1.96^{\mathrm{b}} \pm 0.31$ & $\mathrm{P}<0.05$ \\
\hline Iron $(\mu \mathrm{g} / \mathrm{g})$ & $312.40^{\mathrm{a}} \pm 74.89$ & $95.49^{\mathrm{d}} \pm 45.82$ & $174.16^{c} \pm 56.39$ & $241.61^{b} \pm 56.80$ & $\mathrm{P}<0.05$ \\
\hline Zinc $(\mu \mathrm{g} / \mathrm{g})$ & $6.49^{\mathrm{a}} \pm 1.99$ & $1.96^{c} \pm 0.79$ & $2.66^{b c} \pm 1.60$ & $4.21^{\mathrm{b}} \pm 1.64$ & $\mathrm{P}<0.05$ \\
\hline Lead $(\mu \mathrm{g} / \mathrm{g})$ & $1.44^{\mathrm{a}} \pm 0.69$ & $0.42^{c} \pm 0.60$ & $0.78^{\mathrm{b}} \pm 0.46$ & $1.11^{\mathrm{a}} \pm 0.76$ & $\mathrm{P}<0.05$ \\
\hline Copper $(\mu \mathrm{g} / \mathrm{g})$ & $0.69^{\mathrm{a}} \pm 0.39$ & $0.27^{c} \pm 0.24$ & $0.55^{b c} \pm 0.31$ & $0.77^{a} \pm 0.45$ & $\mathrm{P}<0.05$ \\
\hline Nickel $(\mu \mathrm{g} / \mathrm{g})$ & $2.32^{\mathrm{a}} \pm 0.61$ & $0.99^{c} \pm 0.50$ & $1.59^{\mathrm{b}} \pm 0.44$ & $1.91^{\mathrm{ab}} \pm 0.61$ & $\mathrm{P}<0.05$ \\
\hline Sand (\%) & $81.63^{c} \pm 5.44$ & $87.46^{\mathrm{b}} \pm 4.28$ & $89.55^{\mathrm{ab}} \pm 2.42$ & $92.69^{a} \pm 2.61$ & $\mathrm{P}<0.05$ \\
\hline Clay (\%) & $13.89^{\mathrm{a}} \pm 4.24$ & $9.24^{\mathrm{b}} \pm 3.30$ & $7.64^{b c} \pm 1.81$ & $5.28^{c} \pm 2.33$ & $\mathrm{P}<0.05$ \\
\hline Silt (\%) & $4.49^{\mathrm{a}} \pm 1.65$ & $3.30^{\mathrm{ab}} \pm 1.40$ & $2.81^{b} \pm 1.25$ & $2.04^{\mathrm{b}} \pm 0.54$ & $\mathrm{P}<0.05$ \\
\hline
\end{tabular}

$\mathrm{P}<0.05-$ Significant difference; $\mathrm{P}>0.05-$ No significant difference. 
station 1, the values of the particle matter at stations 2 and 3 were intermediate of the extreme values. Figures 2-5 showed the spatial variations for the various characterized physicochemical parameters.

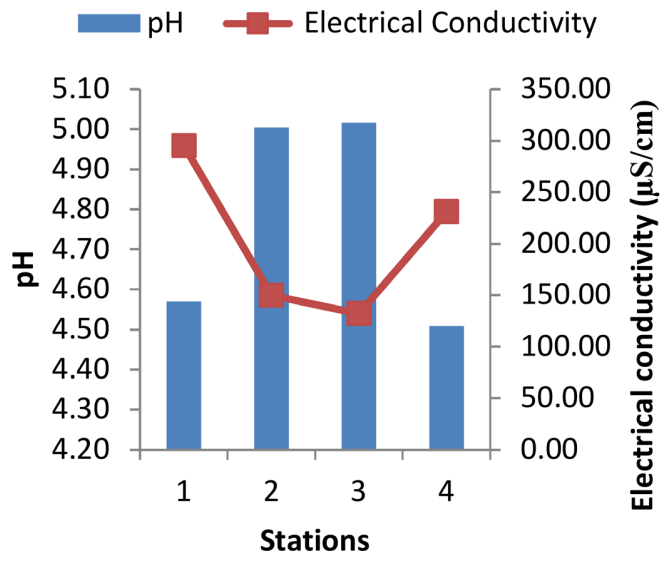

Figure 2. Spatial variations in $\mathrm{pH}$ and electrical conductivity.

- Total Organic Carbon (TOC)

- Total Organic Matter (TOM)

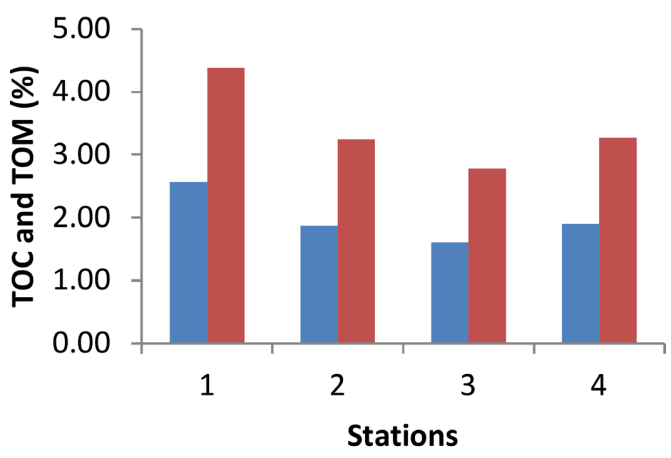

Figure 3. Spatial variations in total organic carbon and total organic matter.

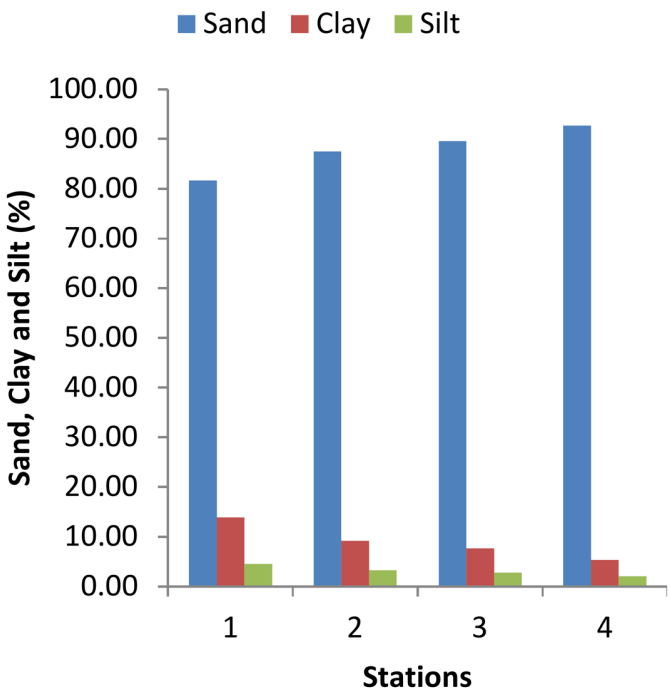

Figure 4. Spatial variations in particle matters. 


\subsection{Multivariate Analysis: Principle Component Analysis (PCA)}

The result of the PCA based on the correlation matrix of sediment physicochemical parameters analyzed is expressed in Table 2. The eigenvector classified

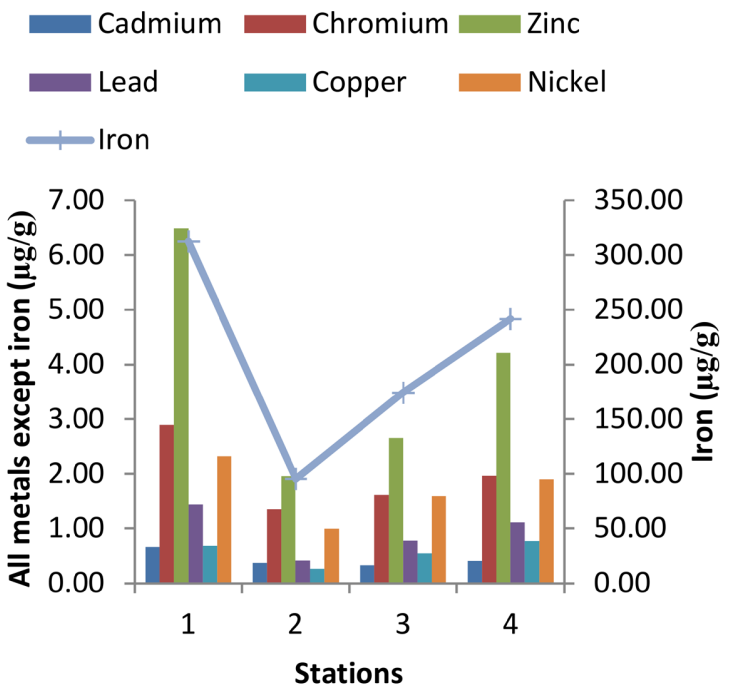

Figure 5. Spatial variations in heavy metals.

Table 2. Eigenvectors and eigenvalues of the various components.

\begin{tabular}{|c|c|c|c|c|}
\hline & \multicolumn{4}{|c|}{ Component } \\
\hline & 1 & 2 & 3 & 4 \\
\hline $\mathrm{Ph}$ & -0.075 & 0.263 & 0.310 & 0.853 \\
\hline $\mathrm{EC}$ & 0.173 & 0.335 & 0.284 & -0.681 \\
\hline TOC & 0.208 & 0.576 & 0.704 & -0.162 \\
\hline TOM & 0.221 & 0.562 & 0.710 & -0.119 \\
\hline $\mathrm{Cd}$ & 0.348 & 0.179 & 0.674 & 0.439 \\
\hline $\mathrm{Cr}$ & 0.802 & 0.237 & -0.072 & -0.257 \\
\hline $\mathrm{Fe}$ & 0.853 & 0.073 & 0.426 & -0.064 \\
\hline $\mathrm{Zn}$ & 0.856 & 0.256 & 0.134 & -0.158 \\
\hline $\mathrm{Pb}$ & 0.854 & 0.086 & 0.306 & 0.209 \\
\hline $\mathrm{Cu}$ & 0.299 & -0.042 & 0.880 & 0.093 \\
\hline $\mathrm{Ni}$ & 0.776 & -0.108 & 0.482 & 0.013 \\
\hline Sand & -0.121 & -0.969 & -0.120 & -0.010 \\
\hline Clay & 0.128 & 0.928 & 0.144 & -0.005 \\
\hline Silt & 0.077 & 0.883 & 0.027 & 0.053 \\
\hline Eigenvalues & 3.812 & 3.587 & 2.972 & 1.574 \\
\hline$\%$ of Variance & 27.225 & 25.624 & 21.229 & 11.242 \\
\hline Cumulative \% & 27.225 & 52.849 & 74.077 & 85.320 \\
\hline
\end{tabular}

TOC-Total organic carbon; TOM-Total organic matter. 
the physicochemical parameters into four components which all together accounted for $85.320 \%$ of the variance in the data set. The contributions were as followed-component 1, 2, 3 and 4 accounted for 27.225\%, 25.624\%, $21.229 \%$ and $11.242 \%$ respectively. The components recorded high eigenvector $>0.600$ as follows for the following parameters: component $1-\mathrm{Cr}, \mathrm{Fe}, \mathrm{Zn}, \mathrm{Pb}$ and $\mathrm{Ni}$; component 2-sand, clay and silt; component 3-TOM, TOC, $\mathrm{Cd}$ and $\mathrm{Cu}$ and component $4-\mathrm{pH}$ and electrical conductivity.

\subsection{Discussion}

Invariably sediment remains the ultimate sink of contaminants in the aquatic systems and this is on it account of variable physical and chemical properties (Mucha et al., 2003 [8]; Praveena et al., 2007 [9]).These contaminants which are either organic or inorganic in nature may easily, slowly or poorly degrade under natural conditions (Davies and Tawari, 2010) [1]. There were minimal temporal and spatial variations in the $\mathrm{pH}$ values of sediment in the study area thus no significant difference $(\mathrm{P}>0.05)$ was observed among the stations. In general, the mean sediment values were acidic in nature, Umesi (1999) [15] and Ezekiel et al. (2011) [16] recorded similar condition in Rumueme Creek and Sombreiro River respectively. This opposes the alkaline condition recorded by Braide et al. (2004) [17] and Wokoma and Friday (2017) [6] in Miniweja stream and Sombreiro River respectively. All these studies were conducted within the Niger Delta area in Nigeria. pH appeared among the most inferential parameters in component 4 and in the same component exhibited an inverse with the electrical conductivity. This relationship implied that the more acidic the sediment becomes, the higher it ionic content and contrariwise. This relationship was obvious in Figure 2 as the stations 2 and 3 with low values of $\mathrm{pH}$ in-turn had high values of electrical conductivity and stations 1 and 4 had high values of $\mathrm{pH}$ and low values of electrical conductivity. Unlike $\mathrm{pH}$, the electrical conductivity differed significantly and the station with the highest value by intra-specific variation was the prime for this observed variation.

Sediment is a major site for organic matter decomposition which is primarily carried out by bacteria and the level of organic matter decomposition may be attributed for the variation in organic carbon content (Daka and Moslen, 2013 [18]; Adesuyi et al., 2016 [19]). The mean total organic carbon content of the study stations in the Okpare creek varied between $1.61 \%$ and $2.57 \%$. This is indicative of high organic carbon content, in line with the position of Gigs (1978) [20] that sediments with values of organic carbon content exceeding $1 \%$ are said to have high organic carbon content.This is comparable to the $2.02 \%-4.134 \%$ and $0.87 \%-2.69 \%$ gotten in the Sombreiro River by Ezekiel et al (2011) [16] and Wokoma and Friday (2017) [6]. However the values obtained were lower than the finding of previous investigations by Umesi et al (2013) [16] in Rumueme Creek which had a range of $2.67 \%-16.00 \%$. In the words of Wokoma and Friday (2017) [6], this difference in the value of total organic carbon may be as a 
result of levels of bacterial decomposition of organic matter in sediment and or variation in the levels of anthropogenic perturbations in the study sites. Total organic carbon one of the major component of matter in soil and sediment, Radojevic and Bashkin (1999) [22] expressed that carbon content of organic matter is generally around $58 \%$. This is applicable to the values of total organic carbon and matter observed in this study. The total organic carbon showed positive correlation with the total organic matter, $\mathrm{Cd}$ and $\mathrm{Cu}$. By this it can be stated that all these parameters are of the same source.

Variations in the heavy metal concentrations showed that stations 1 and 4 had higher concentrations of heavy metals than stations 2 and 3 . With the exception of $\mathrm{Cd}$, the other heavy metals maintained significant differences with trend depicting above variations. Most of the heavy metals ( $\mathrm{Cr}, \mathrm{Fe}, \mathrm{Zn}, \mathrm{Pb}$ and $\mathrm{Ni}$ ) were among the primary factors responsible for the variations in the sediment quality of this aquatic body as this was exemplified by their inclusion among the first component of PCA. Furthermore the inclusion of these parameters to component 1 of the PCA implied that major parameters influenced by anthropogenic likewise natural activities. The PCA result showed that the heavy metal compositions of this system were of two forms: one comprising $\mathrm{Cr}, \mathrm{Fe}, \mathrm{Zn}, \mathrm{Pb}$ and $\mathrm{Ni}$ and the other including $\mathrm{Cd}$ and $\mathrm{Cu}$. This partitioning showed different sources of anthropogenic input other than possible sourcing petroleum exploration as notable within this region. Possible source of the heavy metals input into this aquatic body largely can be non-point in nature and likely agent of input could be storm wash down from hinterland. Fe is the dominant among all the heavy metals characterized. The concentrations of Fe obtained most especially in the various stations were similar to values recorded by Wokoma and Friday (2017) [6] in Sombreiro River but significantly lower than the values with means ranging from 5285.50 to $5841.75 \mathrm{mg} / \mathrm{kg}$ recorded by Nwajei et al. (2014) [23] in Crayford Creek. Further according to Nwajei et al. (2014) [23] the major sources of Fe in the sediment are discharges of municipal wastes, scrap dumps and runoffs. In general, the levels of all the heavy metals characterized in this study complied favourably with the DPR (2002) target values.

The sediment fractions obtained in this study were consistent with those of Nweke (2000) [24] in Elechi Creek, Upper Bonny Estuary, Ebere (2002) [25] in Okrika Creek (Central Bonny Estuary), Davies and Tawari (2010) [1] in TransOkpoka Creek (Upper Bonny Estuary) and Wokoma and Friday (2017) [6] in Sombreiro River. All these workers reported high proportions of sand and low proportions of silt-clay in the Niger Delta Estuaries. However, the findings of this study on sand-silt-clay proportions of the creek were not in accordance with those of Izoafuo et al. (2004) [26] who reported relatively low sand (39.8\% to $65 \%$ and high silt-clay $22 \%$ to $54.7 \%$ ) and clay (5.5\% to $17.2 \%$ ) of the middle reach of Bonny Estuary. Also, this study observation contradicts the report of Ogamba (1998) [27] of high silt fraction (55\%) of sediments from Elechi Creek. The impact of the dredging activities observed in the course of field study was 
expressed in sediment fractions as they all included in the second component of the PCA. The sand composition exhibited an inverse correlation with other fractions; the breakdown of the sand fraction yields the clay and silt. Similar correlation was observed by Davies and Tawari (2010) [1] in Trans-Okpoka Creek (Upper Bonny Estuary).

\section{Conclusion}

Assessment of physicochemical qualities of surface sediment of Okpare creek, Niger Delta was carried out using Principle Component Analysis (PCA) that shows the most influenced parameters include the heavy metals $(\mathrm{Cr}, \mathrm{Fe}, \mathrm{Zn}, \mathrm{Pb}$ and $\mathrm{Ni}$ ) with the exception of cadmium and stations 1 and 4 bore the imprint of these activities more than other stations and ANOVA and Duncan multiple range that shows that the physicochemical parameters differ significantly $(\mathrm{P}<$ 0.05 ) with the exception of $\mathrm{pH}$ and cadmium. Therefore it is needful that urgent action is taken in order to avert loss of biodiversity, loss of means of livelihood and health hazards for the locals.

\section{Acknowledgements}

The authors sincerely appreciate the support of Tudaka Environmental Consultants Warri, Dr Samuel Ejoh and Mr Ifeanyi Ezenwa during the period of the research work.

\section{Conflicts of Interest}

The authors declare no conflicts of interest.

\section{References}

[1] Davies, O.A. and Tawari, C.C. (2010) Season and Tide Effects on Sediment Characteristics of Trans-Okpoka Creek, Upper Bonny Estuary, Nigeria. Agriculture and Biology Journal of North America, 1, 89-96.

[2] Ite, A.E., Ibok, U.J., Ite, M.U. and Peters, S.W. (2013) Petroleum Exploration and Production: Past and Present Environmental Issues in the Nigeria's Niger Delta. American Journal of Environmental Protection, 1, 78-90. https://doi.org/10.12691/env-1-4-2

[3] Farouk, A.E. and Ahmed, S.M. (2019) Physical, Chemical Properties Assessment and Accumulation of Some Heavy Metals in Sediment of Edku Lake, Egypt. Egyptian Journal of Aquatic Biology \& Fisheries, 23, 461-476. https://doi.org/10.21608/ejabf.2019.70595

[4] Hasaballah, A.F., Hegazy, T.A., Ibrahim, M.S. and El-Emam, D.A. (2019) Assessment of Water and Sediment Quality of the River Nile, Damietta Branch, Egypt. Egyptian Journal of Aquatic Biology \& Fisheries, 23, 55-65. https://doi.org/10.21608/ejabf.2019.64835

[5] USEPA (2001) Method for Assessing the Chronic Toxicity of Marine and Estuarine Sediment-Associated Contaminants with the Amphipod Leptocheirus plumulosus. US Environmental Protection Agency, Office of Water, Washington DC.

[6] Wokoma, O.A.F. and Friday, U. (2017) The Sediment Physicochemical Characteris- 
tics in Sombreiro River, Rivers State, Nigeria. International Journal of Innnovation, 7, 16-21.

[7] Elijah, I.O., Gbolagade, J. and Steve, O.A. (2008) Variations in Heavy Metal Concentrations Following the Dredging of an Oil Well Access Canal in the Niger Delta. Advances in Biological Research, 2, 97-103.

[8] Mucha, A.P., Vasconcelos, M.T.S.D. and Bordalo, A.A. (2003) Macrobenthic Community in the Douuro Estuary: Relation with Trace Metals and Natural Sediment Characteristics. Environmental Pollution, 121, 169-180. https://doi.org/10.1016/S0269-7491(02)00229-4

[9] Praveena, S.M., Radojevic, M., Abdullah, M.H. and Aris, A.Z. (2007) Application of Sediment Quality. Guidelines in the Assessment of Mangrove Surface Sediment in Mengkabong Lagoon, Sabah, Malaysia. Global Journal of Environmental Research, 1, 96-102.

[10] Yu, K.C., Tsai, L.T., Chen, S.H. and Pick, F.R. (2001) Correlation Analysis on Ling Behavior of Heavy Metals with Sediment Matrices. Water Research, 35, 2417-2428. https://doi.org/10.1016/S0043-1354(00)00518-2

[11] Wepener, V. and Vermulen, L.A. (2005) Concentrations and Bioavailability of Selected Metals in Sediments of Richard Bay Harbour, South Africa. Water SA, 31, 589-595. https://doi.org/10.4314/wsa.v31i4.5149

[12] Ejoh, S.A., Unuakpa, B.A., Imoobe, T.O.T. and Edeki, S.O. (2018) Dataset on Community Structure of Macro Invertebrate Fauna in Ubogo River, Udu LGA, Delta State, Nigeria. Data in Brief, 19, 763-768. https://doi.org/10.1016/j.dib.2018.05.084

[13] Ejoh, A.S., Unuakpa, B.A., Ibadin, F.H. and Edeki, S.O. (2018) Dataset on the Assessment of Water Quality and Water Quality Index of Ubogo and Egini Rivers, Udu LGA, Delta State Nigeria. Data in Brief, 19, 1716-1726. https://doi.org/10.1016/j.dib.2018.06.053

[14] Shell Petroleum Development Company (SPDC, EIA) (2004) Environmental Impact Assessment of Afisere, Eriemu, Otorogu and Uzere for Oil Field. Development Scooping Workshop for EIA Process, Warri, May 2004, 2-6.

[15] Umesi, N. (1999) Sediment Quality and Macro Faunal Benthos of the Rumueme Creek in the Upper Limits of the Bonny River. M. Phil. Thesis, Rivers State University of Science and Technology, Port Harcourt.

[16] Ezekiel, E.N., Hart, A.I. and Abowei, J.F.N. (2011) The Sediment Physical and Chemical Characteristics in Sombreiro River, Niger Delta, Nigeria. Research Journal of Environmental and Earth Sciences, 3, 341-349.

[17] Braide, S.A., Izunfuo, W.A.L., Adiukwu, P.U., Chindah, A.C. and Obunwo, C.C. (2004) Water Quality of Miniweja Stream, a Swamp Forest Stream Receiving NonPoint Water Discharges in Eastern Niger Delta, Nigeria. Scientia Africana, 3, 1-8.

[18] Daka, E.R. and Moslen, M. (2013) Spatial and Temporal Variation of Physicochemical Parameters of Sediment from Azuabie Creek of the Upper Bonny Estuary, Niger Delta. Research Journal of Environmental and Earth Sciences, 5, 219-228. https://doi.org/10.19026/rjees.5.5717

[19] Adesuyi, A.A., Ngwoke, M.O., Akinola, M.O., Njoku, K.L. and Jolaoso, A.O. (2016) Assessment of Physicochemical Characteristics of Sediment from Nwaja Creek, Niger Delta, Nigeria. Journal of Geoscience and Environment Protection, 4, 16-27. https://doi.org/10.4236/gep.2016.41002

[20] Gigs, G. (1978) An Investigation of Bottom Sediments in a Polluted Marine Environment, Upper Saronikos Gulf, Greece. Report to the Environmental Pollution 
Control Project, Athens.

[21] Umesi, N., Dirisu, G.N.G., Nwogbidi, K.C. and Wokoma, O.A.F. (2013) Effects of Organic Carbon and Dissolved Oxygen on Species Diversity of Littoral Benthos in Sites around the Rumueme Creek in the Upper Bonny Estuary. Asian Journal of Natural and Applied Science, 2, 31-40.

[22] Radojevic, M. and Bashkin, V.N. (1999) Practical Environmental Analysis. Royal School of Chemistry, Thomas Graham House, Cambridge, 645 p.

[23] Nwajei, G.E., Dibofori-Orji, A.N., Iwegbue, C.M.A. and Ojuh, B.O. (2014) Distribution of Trace Elements in Surface Water and Sediments from Crayford Creek in Warri, Delta State of Nigeria. Academic Research International, 5, 123-134.

[24] Nweke, A.N. (2000) Impact of Organic Wastes Pollution on the Macro-Benthos and Fish Fauna of Elechi Creek. PhD Thesis, Department of Biological Sciences, The Rivers State University of Science and Technology, Port Harcourt, 287 p.

[25] Ebere, N. (2002) The Impact of Oil Refinery Effluents on the Distribution, Abundance and Community Structure of Macro-Benthos in Okrika Creek. PhD Thesis, Department of Biological Sciences, The Rivers State University of Science and Technology, Port Harcourt, 383 p.

[26] Izoafuo, W.A.I., Chindah, A.C., Braide, S.A. and Iyalla, I.A. (2004) An Assessment of Sediment Quality at the Vicinity of Marine Landing Jetties at the Middle Reach of Bonny Estuary, Niger Delta. Scientia African, 3, 1-10.

[27] Ogamba, N.E. (1998) Baseline Survey of the Fisheries of Elechi Creek. M.Sc. Thesis, Department of Biological Sciences, Rivers State University of Science and Technology, Port Harcourt, 91 p. 